\title{
Arsenic in cattle: Evaluation of possible exposure biomarkers
}

\author{
C.V. Alvarez-Gonçalvez, F.E. Arellano, A. Fernández-Cirelli \& A.L. Pérez Carrera \\ Instituto de Investigaciones en Producción Animal UBA-CONICET (INPA), CONICET - Universidad de Buenos \\ Aires, Buenos Aires, Argentina \\ Centro de Estudios Transdisciplinarios del Agua (CETA), Universidad de Buenos Aires, Buenos Aires, Argentina \\ Cátedra de Química Orgánica de Biomoléculas, Universidad de Buenos Aires, Buenos Aires, Argentina
}

\begin{abstract}
Arsenic pollution is naturally present in groundwater and soils of the main agriculture production areas in Argentina. Arsenic can be taken up and bioaccumulated by forages, and may be bio-transferred to animals, food and humans. Blood and hair are generally used in humans as biomarkers but there is a lack of information in livestock. This study shows that As levels in cattle hair from As affected area were significantly higher than in the control area. In analyzed blood samples no significant differences were found between control and As affected areas. Blood appear not to be an effective biomarker in cattle such as it has been determinate for human but hair may indicate chronic exposure in cattle.
\end{abstract}

\section{INTRODUCTION}

Arsenic (As) pollution affects several countries around the world. One of the most affected countries is Argentina, where As is naturally present in groundwater and soils of the main agriculture production areas (Bundschuh et al., 2012). Arsenic can be taken up and bioaccumulated in plants and livestock, which means a potential risk to human health through agri-food.

Presence of toxic substances in blood is a known exposure biomarker (Lowry et al., 1989). On the other hand, in the case of As, its levels in cattle hair might be used as another biomarker exposure. Even though, it is commonly used for humans, there is a severe lack of knowledge for other animal species.

The aim of this study is to assess total arsenic levels in soils and drinking water from cattle farms; and to analyze the relationship with blood and hair As content in cattle.

\section{MATERIAL AND METHODS}

This study was carried out in the Pampean Plain (Argentina). The study area is one of the most important livestock production regions. The samples zones were located in Buenos Aires province (Control area) and in the southeast of Cordoba province (As affected area).

Soil and drinking water samples were taken up from livestock production systems and dairy farms. Soil samples correspond to surface soil $(0$ to $20 \mathrm{~cm}$ deep). Samples were collected along transect in the field at regular intervals. Arsenic determination was according to ISO 11466 (1995). Soils were digested using a mixture of nitric and hydrochloric acids $(1: 3)$ at $120^{\circ} \mathrm{C}$ during $2 \mathrm{~h}$ with reflux. Water samples correspond to groundwater used for cattle. They were collected in polypropylene tubes, acidified at $20 \%$ with $\mathrm{HNO}_{3}$ and conserved refrigerated at $4{ }^{\circ} \mathrm{C}$. Blood and hair samples were collected from adult and female Holando cows. The samples were digested with $\mathrm{HNO}_{3}$ at hot plate. Arsenic in all samples were determined by inductively coupled plasma optical emission spectrometry (ICP-OES, Optima 2000, Perkin Elmer).

\section{RESULTS AND DISCUSSION}

Usually, arsenic in soils ranged between 1 to $95 \mathrm{mg} \mathrm{kg}^{-1}$ (Kabata \& Pendias, 2001), and in groundwater (main water source for animal drinking in the Pampean Plain) arsenic is documented in the literature up to values of $5000 \mu \mathrm{g} \mathrm{L}^{-1}$ (Ravenscroft et al., 2009). Maximum total As content for animal drinking water and soil destined to agricultural activities in Argentina are $0.5 \mathrm{mg} \mathrm{L}^{-1}$ and $20 \mathrm{mg} \mathrm{kg}^{-1}$ respectively (Law 24.051), but the international guidelines recommend a maximum level of As in animal drinking water $200 \mu \mathrm{g} \mathrm{L}^{-1}$ (FAO, 1985) and in agricultural soil $17 \mathrm{mg} \mathrm{kg}^{-1}$ (CCME, 2001). The As levels for all samples analyzed in this study are shown in Table 1.

It is known that drinking water is the main As source for cattle (Perez Carrera et al., 2012, 2016), the levels obtained through forage and fodder or accidental soil take up is relatively low. In the analyzed soil samples, As levels were below the detection limit $\left(\mathrm{LD}=3.5 \mathrm{mg} \mathrm{kg}^{-1}\right)$.

Regarding to As level in hair, in all samples from control area, were below $1000 \mathrm{ng} \mathrm{g}^{-1}$. In affected areas 
Table 1. Arsenic levels (min-max.) for water, cattle's hair and blood in affected and control areas.

\begin{tabular}{llll}
\hline Area & $\begin{array}{l}\text { Water } \\
\mu \mathrm{g} \mathrm{L}^{-1}\end{array}$ & $\begin{array}{l}\text { Hair As } \\
\mathrm{ng} \mathrm{g}^{-1}\end{array}$ & $\begin{array}{l}\mathrm{Blood} \mathrm{As} \\
\mu \mathrm{L} \mathrm{L}^{-1}\end{array}$ \\
\hline $\begin{array}{l}\text { Affected area } \\
\text { Control area }\end{array}$ & $\begin{array}{l}51-268 \\
<L D-50\end{array}$ & $\begin{array}{l}<\mathrm{LD}-1520 \\
<\mathrm{LD}-520\end{array}$ & $\begin{array}{l}<\mathrm{LD}-75 \\
<\mathrm{LD}\end{array}$ \\
\hline
\end{tabular}

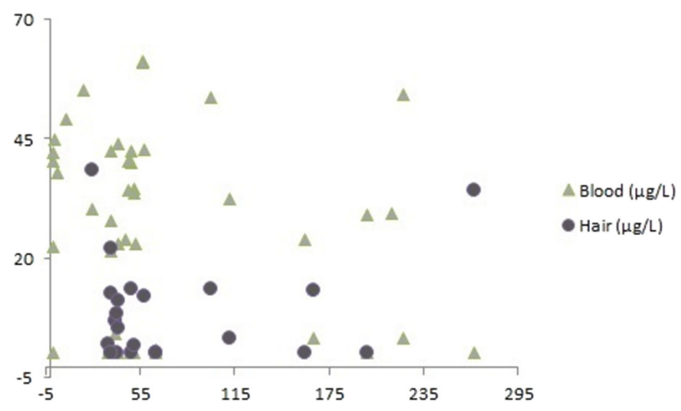

Figure 1. Relationship between total arsenic $\left(\mu \mathrm{gL}^{-1}\right)$ in blood and hair with water As concentration. $\mathrm{X}$ axis show As levels in water while $\mathrm{Y}$ axis shows As levels in blood and hair.

As hair levels were between $<$ LD-1520. In cattle there are no enough data to determine a confident baseline value. These results are according to previous studies (Pérez Carrera \& Fernandez Cirelli, 2012).

Arsenic levels in cattle blood were between $<$ LD $75 \mu \mathrm{g} \mathrm{L}^{-1}$. These values are below than those previously reported by Rana et al. $(2008,2010)$ in West Bengal, India, that inform mean levels in blood of $284 \mu \mathrm{g} \mathrm{L}^{-1}$. Relationship between total As level in drinking water and As levels in blood and hair should be of relevance. However, no significant correlation $(\mathrm{p}>0.05)$ was observed. Results are shown in Figure 1.

\section{CONCLUSIONS}

Total As concentration in $50 \%$ of water samples exceeded the recommended value for cattle $\left(200 \mu \mathrm{g} \mathrm{L}^{-1}\right)$ in the affected area. Blood appear not to be an effective biomarker for chronic exposure in cattle. Regards hair values in affected area were significantly higher than values determined in the control area and may be used as exposure biomarkers.

\section{ACKNOWLEDGEMENTS}

The authors are grateful to the University of Buenos Aires and CONICET for financial support.

\section{REFERENCES}

Bundschuh, J., Litter, M.I., Parvez, F., Román-Ross, G., Nicolli, H.B., Jean, J.-S., Liu, C.-W., López, D., Armienta, M.A., Guilherme, L.R.G., Cuevas, A.G., Cornejo, L., Cumbal, L. \& Toujaguez, R. 2012. One century of arsenic exposure in Latin America: a review of history and occurrence from 14 countries. Sci. Total Environ. 429: $2-35$.

CCME-Canadian Council of Ministers of the Environment. 2001. Canadian soil quality guidelines for the protection of the environmental and human health: Arsenic (inorganic) (1997). Updated in: Canadian environmental quality guidelines, 1999, Canadian Council of Ministers of the Environment, Winnipeg.

FAO-Food and Agriculture Organization 1985. Water quality for agriculture. Rome: Food and Agriculture Organization of the United Nations.

ISO 11466. 1995. Soil Quality - Extraction of trace element soluble in aqua regia.

Kabata P.A. \& Pendias, H. 2010. Trace Elements in Soils and Plants. Third edition, CRC Press, Boca Raton, Ann Arbor, London.

Lowry, L.K. 1995. Role of biomarkers of exposure in the assessment of health risks. Toxicology letters 77(1-3): 31-38.

Perez-Carrera, A.L. \& Fernandez-Cirelli, A. 2012. Arsenic exposure in cows from high contaminated area in the Chaco Pampean plain, Argentina. Proceedings of the 4th International Congress on Arsenic in the Environment, 22-27 July 2012, Cairns, Australia.

Pérez-Carrera, A., Alvarez-Gonçalvez, C.V. \& FernándezCirelli, A. 2016. Transference factors as a tool for the estimation of arsenic milk concentration. Environ. Sci. Pollut. Res. 23(16): 16329-16335.

Rana, T., Sarkar, S., Mandal, T.K., Bhattyacharyya, K. \& Roy, A. 2008. Arsenic residue in blood, urine and faeces samples from cattle in the Nadia district of West Bengal in India. Internet J. Vet. Med. 4(1).

Rana, T., Bera, A.K., Das, S., Bhattacharya, D., Bandyopadhyay, S., Pan, D. \& Das, S.K. 2010. Effect of chronic intake of arsenic-contaminated water on blood oxidative stress indices in cattle in an arsenic-affected zone. Ecotoxicol. Environ. Saf. 73(6), 1327-1332.

Ravenscroft P., Brammer H. \& Richards K. Arsenic Pollution: A Global Synthesis. West Sussex, UK: John Wiley \& Sons; 2009. 